\title{
The Evaluation of Customer Satisfaction with the Third Party Logistics Service Quality for Online Shopping
}

\author{
Hongzhang Chen ${ }^{1, *}$, Yawei $\mathbf{Q i}^{2}$ \\ ${ }^{1}$ The Collaborative Innovation Center, Jiangxi University of Finance, China \\ ${ }^{2}$ School of Information Technology, Jiangxi University of Finance, China
}

Copyright $\bigcirc 2016$ by authors, all rights reserved. Authors agree that this article remains permanently open access under the terms of the Creative Commons Attribution License 4.0 International License

\begin{abstract}
Low logistics service quality is a key factor restricting the development of e-commerce. In order to improve customer satisfaction, this paper establishes an index system to evaluate customer satisfaction with the third party logistics service quality, and design the questionnaire according to the evaluation index. With the original data, we construct four quadrants with the dimensions of satisfaction and importance to analyze the reliability and validity of third-party logistics service. The results show that logistics service speed is the most important determinant of customer satisfaction and that the importance of risk perception is the lowest. Moreover, the accuracy of a service rate is satisfied at the highest level and the integrity of goods is satisfied at the lowest degree. This paper contributes by designing the specific measures and uncovering the determinants to improve the satisfaction of logistics service for online shopping.
\end{abstract}

Keywords Logistics Service Quality, Customer Satisfaction, Evaluation, Online Shopping

\section{Introduction}

With the rapid development of information and the mobile Internet technology, online shopping becomes a fashion. Because the online shopping is convenient, quick, inexpensive, and unrestricted by time and place, it has been unknowingly changing consumption habits and will gradually become the main consumption channel. When online shopping promotes the flourish of electronic commerce, it also intrigues new problems. For example, when we interview consumers, we find some comments as follows.

"I bought a mobile phone online. The shopkeeper says that it must be a certified product but it is a fake one. The seller doesn't return or exchange until I give a positive feedback with phone harassment". "Goods haven't been sent off for more than 20 days. What a slow speed it is!".
Many consumers had similar complaints, especially in this online shopping environment, where sellers are unable to communicate directly with consumers. Consumers' dissatisfaction leads many consumers to lose confidence in sellers and network shopping. Therefore, customer satisfaction becomes the key to electronic commerce development.

The rapid development of China e-commerce is based on the extensive participation of the third party logistics enterprises. However, customer satisfaction on the logistics has been at a low level such that it becomes the development bottleneck. According to the statistics data of online shopping in 2014, users' satisfaction degree on logistics is only $80.1 \%$, in which $8 \%$ of users believe that the delivery time is too long, $4 \%$ of users believe that the deliveryman's attitude is not good, and 3\% of users goods are lost or damaged during the transmission. Thus, in the online shopping environment, to understand and measure the determinants of logistics services satisfaction to improve the logistics service satisfaction has become a hot issue of common concern. To improving consumer's confidence and loyalty in networking products and promote the vigorous development of e-commerce, the customer satisfaction evaluation on logistics services for online shopping is significant.

\section{Literature Review}

As the existing literature indicates, online shopping has a group of advantages, but Lin Minhui (2013) points out that the development of China's online shopping generates the problems such as low degree of logistics informatization and marketization, weak infrastructure, imperfect distribution channels, lack of efficient logistics network, low education of logistics service personnel who lack the understanding on the logistics professional knowledge.

Oliver and Richard (1999) pointed out that the logistics service quality is the most important factor of customer satisfaction. Colier (1991) argued that a third party should evaluate logistics service quality with reference to operations and sales. Mentzer (1999-2001) subdivided the logistics 
service quality into nine dimensions including logistics. Stank (2003) divided logistics service quality in three parts: operation quality, quality and cost quality. Kingsly and Li (2006), Xu(2006) and Zheng et al. (2007) set model up with five dimensions of logistics service quality including the order quality, personalized service quality, respond to the quality, delivery quality and error handling. They also studied the relationship among the five dimensions further by experiments. Precisely, they found that, in the $\mathrm{B} 2 \mathrm{C}$ online shopping, the subjective judgment of consumers on the logistics service quality is one of the main factors for the potential next visit. Ye (2011) found that logistics interactions and operation quality affects customer satisfaction with the third party logistics service providers, and the cost of quality has no effect on customer satisfaction. From the customer's perspective, Huang and Joyce (2014) discussed the dimensions of the logistics service quality for domestic online shopping. They analyzed the short board issue of third logistics party for Chinese e-commerce development.

In the online shopping, consumers do not contact with shipping companies, but often realize distribution risk. Urban (2005) put forward that risk distribution expected by consumers will affect the confidence and trust in the online shops and online shopping. Esper et al. (2010) found the timely arrival, the expected integrity, delivery satisfaction and the logistics enterprise reliability are the main variables to affect the consumers' online shopping attitude and decisions. Wang and $\mathrm{Li}$ (2013) analyzed the types and characteristics of virtual logistics risk, and demonstrated in detail the identification of virtual logistics risk. With the view of enterprise users, $\mathrm{Li}$ (2013) discussed the factor of consumer perception on the third party logistics outsourcing and evaluated the customer loyalty on the third party logistics enterprise.

Combining the above literature, we found that there is no appropriate literature on the quantitative evaluation study on the customer satisfaction on logistics service. Most of the existing literature overlook whether the perceived risk on logistics distribution affects customer satisfaction. This paper compares the online shopping environment and the construction of the real logistics customer satisfaction dimensions, combining the quality in dealing with online shopping environment.

\section{A New Evaluation System on Customer Satisfaction}

Based on the characteristics of logistics service for online shopping, the article establishes a customer satisfaction index system on the third party logistics service. Precisely, we consider eight factors, including logistics services speed, logistics service price, service personnel quality, accuracy, integrity, logistics information timeliness, error processing quality, customer perceived risk. The following explains the specific meaning of the indicators in detail.

\section{Logistics service speed}

Speed of logistic service refers to whether the goods arrive at the appointed place within the expected time. It includes the length of time from place the order to the order finished. It is affected by the length of time to reset the order, transport time and error processing time. The speed is affected by the logistics services, delivery speed, and other logistics enterprises' service speed. Generally speaking, faster the logistics service is, higher customer satisfaction would be.

\section{Logistics service price}

The fee paid for the logistics service is stipulated by the third party logistics enterprise. To evaluate logistics service price, we consider the following two factors. One is value for money, which reflects whether the goods are worth paying for. The other one is the relative price. Compared to the prices in the same industry, the relative price represents whether the price is reasonable or not. In general, if the service quality has no difference, the lower logistics service price corresponds to the higher customer satisfaction.

\section{Service attitude}

The logistics service attitude includes actively contact with customers, the timely goods delivery, patient attitude, no signing for customers without authorization, and no disorderly manipulation in the process of downloading. Generally speaking, the kindlier the service attitude is, the higher the customer satisfaction should be.

\section{Logistics service accuracy}

The logistics service accuracy involves the timely delivery and arrival and the safety of goods in delivery. Generally speaking, the higher logistics services accuracy is, the higher the customer satisfaction should be.

\section{Integrity}

Integrity refers to the damage of the goods received by consumers and the efficiency of negotiation after damages. It requires that packaging is not broken or opened, that items have no friction or scratch marks and that items are not crushed. Generally speaking, the greater integrity is, the higher the customer satisfaction should be.

\section{Logistics information timeliness}

It refers to the information timeliness and convenience and the sufficiency of the logistics information, including the information for goods tracking and information updating. Generally speaking, richer logistics information is, the higher the customer satisfaction should be.

\section{Error processing quality}

The previous relevant studies are mainly concentrated on the study on the efficiency of time and space, but rarely on the influence of the error handling on customer satisfaction. Error processing quality involves the entire process efficiency for any error resolution. If the customer did not receive goods on the specified time and place or if the quality 
of the goods has problems, he will report or complain to online sellers or the third party logistics enterprise. Thus, the third party's handling error quality will directly affect the customers' satisfaction on logistics services.

In this paper, error processing quality refers to logistics channels of customer complaints, response time, and processing timeliness. The quality of customer complaint channels is measured by the generality and smooth of customer complaint channels broad. The response time is measured by the time interval from the receipt of customer complaints to the reply to customer complaints. The responding within 24 hours is better. The process timeliness requires sufficient logistics staff to promptly solve customer complaints. In general, the higher the error processing quality is, the higher the customer satisfaction should be.

\section{Customer perceived risk}

A perceived risk derives from information asymmetry. It exists during the whole process of online shopping, especially at the goods confirmation stage (before purchase) and the evaluation stage (after purchase), a perceived risk directly affects consumer confidence in online shopping and his satisfaction. Normally, there are a series of uncertainties on electronic payment on other elements. Consumers are likely to bear the corresponding risk and lose their confidence on the network shopping.

This article divides customer perceived risk into time risk, economic risk and privacy risk. Among them, the time risk refers to the loss because of delay or wrong transport of goods; economic risk refers to consumer economic loss such as damage or leakage during the distribution of goods; and privacy risk refers to the leakage of the consumers' private information such as the consumer's telephone and address.

\section{Customer Satisfaction Questionnaire}

\subsection{The Design and Distribution of the Questionnaire}

This article adopts a questionnaire survey to evaluate the logistics service quality. The questionnaire is divided into three parts. The first part, the background of the respondents involves six basic questions, including gender, occupation, age, level of education, income, and history of online shopping. With the basic information of respondents, we can distinguish whether respondents belong to the target population to ensure the reliability and validity of the questionnaire. The second part surveys the respondents' past experience of online shopping. It includes three questions, whether the respondents concern with logistics service quality for the online shopping, what is delivery choice, what is the third party logistics company chosen. The third part as the core part of the questionnaire includes 12 questions.

This article uses level 5 Likert scale to conduct customer satisfaction assessment, which is divided into five levels including "not satisfied at all", "not very satisfied", "general", "satisfied", "very satisfied". Level 5 Likert scale easily lead to the distribution of customer satisfaction is biased. In order to eliminate the biased distribution and increase distinguish ability of Level 5 Likert scale, we uses hundred-mark system, matching satisfaction level and satisfaction score roughly in Table 1 . Consumers are unlikely to be very satisfied with logistics service, and the probability of consumers being not satisfied at all with logistics service is very small. So the level "not satisfied at all" corresponds to the score over 0-30, level "very satisfied" corresponds to the score 90-100, and the range of other level is 20 s uniformly.

Table 1. The correspondent between satisfaction scores and satisfaction levels

\begin{tabular}{|c|c|c|c|c|c|}
\hline Satisfaction & $\begin{array}{c}\text { Not } \\
\text { satisfied } \\
\text { at all }\end{array}$ & $\begin{array}{c}\text { Not } \\
\text { very } \\
\text { satisfied }\end{array}$ & General & Satisfied & $\begin{array}{c}\text { Very } \\
\text { satisfied }\end{array}$ \\
\hline Score & $0-30$ & $30-50$ & $50-70$ & $70-90$ & $90-100$ \\
\hline
\end{tabular}

We issue 150 questionnaires to teachers and students of the Jiangxi University of Finance and Economics, with the methods of traditional paper-based questionnaire and online questionnaire. Respondents answer the questionnaires according to their real shopping experience. Finally, 130 sets of questionnaires were taken back and 118 sets are effective, i.e., the effective recovery rate was $78.7 \%$.

\subsection{Reliability and Validity Analysis}

We test the reliability and validity of questionnaire. Reliability test mainly adopts Cronbach alpha coefficients. The consistency between the evaluation rating scale score is reflected by the internal consistency coefficient. This article adopts SPSS 21 to conduct consistency examination on eight items of the evaluation index in the satisfaction model; the results are showed in Table 2. The alpha coefficients of eight variables is greater than 0.7 ; the alpha coefficient of the total variables is greater than 0.9 , both of which show that the questionnaire data are highly reliable.

Table 2. A coefficient of research variables

\begin{tabular}{|c|c|c|c|}
\hline Variables & Code & Coefficient & $\begin{array}{c}\text { Comprehensive } \\
\text { a coefficient }\end{array}$ \\
\hline Service speed & SQ & 0.801 & \multirow{2}{*}{} \\
\hline Service price & PQ & 0.869 & \\
\cline { 1 - 2 } Service attitude & PCQ & 0.869 & \multirow{2}{*}{0.934} \\
\hline Service accuracy & CQ & 0.849 & \multirow{2}{*}{0.777} \\
\hline Integrity & DQ & 0.813 & \\
\hline Information timeliness & IQ & 0.872 & \\
\hline Error processing quality & DHQ & 0.872 & \\
\hline Perceived risk & PRQ & 0.878 & \\
\hline
\end{tabular}

This article also uses the factor analysis to test the structural validity of customer satisfaction on the third-party logistics service quality for the online shopping. We conduct KMO test and Bartlett sphere test to examine whether factor analysis is suitable or not. The results are provided in Table 3.

Table 3. KMO test and Bartlett Sphere test

\begin{tabular}{|c|c|c|}
\hline \multicolumn{2}{|c|}{ KMO } & 0.82 \\
\hline \multirow{3}{*}{ Bartlett Sphere test } & Chi-square & 2486.05 \\
\cline { 2 - 3 } & Df & 133 \\
\cline { 2 - 3 } & Siginificance & 0.000 \\
\hline
\end{tabular}


Table 4. Factor Analysis

\begin{tabular}{|c|c|c|c|c|c|c|c|c|c|}
\hline \multicolumn{10}{|c|}{ Total Variance Explained } \\
\hline \multirow[b]{2}{*}{ Component } & \multicolumn{3}{|c|}{ Initial Eigenvalues } & \multicolumn{3}{|c|}{ Extraction Sums of Squared } & \multicolumn{3}{|c|}{ Rotation Sums of Squared Loadings } \\
\hline & Total & $\begin{array}{c}\% \text { of } \\
\text { Variance }\end{array}$ & $\begin{array}{c}\text { Cumulative } \\
\%\end{array}$ & Total & $\begin{array}{c}\% \text { of } \\
\text { Variance }\end{array}$ & $\begin{array}{c}\text { Cumulative } \\
\%\end{array}$ & Total & $\begin{array}{c}\% \text { of } \\
\text { Variance }\end{array}$ & $\begin{array}{c}\text { Cumulative } \\
\%\end{array}$ \\
\hline 1 & 7.316 & 91.446 & 91.446 & 7.316 & 91.446 & 91.446 & 4.425 & 55.317 & 55.317 \\
\hline 2 & 1.574 & 7.173 & 98.619 & 0.574 & 7.173 & 98.619 & 3.464 & 43.302 & 98.619 \\
\hline 3 & 0.104 & 1.297 & 99.916 & & & & & & \\
\hline 4 & 0.007 & 0.084 & 100 & & & & & & \\
\hline 5 & 0.0006 & 0.0013 & 100 & & & & & & \\
\hline 6 & 0.0005 & 0.0009 & 100 & & & & & & \\
\hline 7 & 0.0005 & 0.0010 & 100 & & & & & & \\
\hline 8 & 0.0001 & 0.0001 & 100 & & & & & & \\
\hline
\end{tabular}

As Table 3 shows, KMO coefficient is greater than 0.8 ; Bartlett ball test value equals 2486.05. The corresponding probability $\mathrm{P}$-value is approximately 0 ; this indicates that the correlation coefficient matrix is different from the unit matrix. These coefficients indicate that our variables are suitable for factor analysis.

We conduct factor analysis and rotated component analysis. The results are provided in Table 4 and Table 5. The results show that the eigenvalues of the first two factors is greater than 1; it explained variance accounted for $98.6 \%$ of a total variance $(>50 \%)$. We then extract the first two factors as the common factors. The corresponding load of each item in the questionnaire on the common factor is greater than 0.4 , which indicates that the scale has a good structural validity, and we will not delete a variable. The loading of service speed, information timeliness and integrity in factor 1 are greater, while the loading of service price, service accuracy and service attitude in factor 2 are greater, showing that the above factors are the key factors that affect customer satisfaction.

Table 5. Rotated Component Matrix

\begin{tabular}{|c|c|c|}
\hline Variables & Factor 1 & Factor 2 \\
\hline Service speed & 0.9023 & -0.0917 \\
\hline Service price & 0.1248 & -0.8753 \\
\hline Service attitude & -0.2185 & 0.6582 \\
\hline Service accuracy & -0.1983 & 0.7723 \\
\hline Integrity & -0.5681 & -0.2174 \\
\hline $\begin{array}{c}\text { Information } \\
\text { timeliness }\end{array}$ & 0.6716 & -0.0319 \\
\hline $\begin{array}{c}\text { Error processing } \\
\text { quality }\end{array}$ & 0.1625 & -0.4628 \\
\hline Perceived risk & -0.4529 & 0.1392 \\
\hline
\end{tabular}

\section{Evaluation of Third-party Logistics Customer Satisfaction}

\subsection{The Satisfaction Evaluations of Third Party Logistics services}

A total of 130 questionnaires are taken back, but we found the answers are obviously unreasonable (For example, all the answers are same) or some questions don't be answered of 12 questionnaires, so 118 valid questionnaires are usable. Descriptive statistical analysis of questionnaires is shown in Table 6.

Table 6. Basic information of respondents

\begin{tabular}{|c|c|c|}
\hline Gender & Number & Percentage $(\%)$ \\
\hline male & 53 & 44.90 \\
\hline female & 65 & 55.10 \\
\hline \multicolumn{3}{|c|}{ Age } \\
\hline $\begin{array}{c}18 \text { years old and } \\
\text { younger }\end{array}$ & 13 & 11.00 \\
\hline 18-22 years old & 64 & 54.20 \\
\hline 23-28 years old & 36 & 30.50 \\
\hline 29 years old and elder & 5 & 4.20 \\
\hline \multicolumn{3}{|c|}{ The degree of education } \\
\hline College or below & 38 & 32.20 \\
\hline Undergraduate course & 62 & 52.50 \\
\hline Graduate or above & 18 & 15.30 \\
\hline \multicolumn{3}{|c|}{ The monthly consumption } \\
\hline Less than $800 \mathrm{RMB}$ & 37 & 31.40 \\
\hline 800-1200 RMB & 54 & 45.80 \\
\hline 1200-2000 RMB & 18 & 15.30 \\
\hline More than $2000 \mathrm{RMB}$ & 9 & 7.60 \\
\hline
\end{tabular}

According to customers' selection in every questionnaire, we evaluate eight indicators to determine the weight of each evaluation index, namely the importance of what. The results are shown in Table 7. 
Table 7. Logistics service index statistics of the importance and satisfaction

\begin{tabular}{|c|c|c|c|c|c|c|c|c|}
\hline & \multirow{2}{*}{$\begin{array}{l}\text { Importance } \\
\text { score }\end{array}$} & \multirow{2}{*}{ Importance } & $\begin{array}{c}\text { Not satisfied at } \\
\text { all }\end{array}$ & $\begin{array}{l}\text { Not very } \\
\text { satisfied }\end{array}$ & General & Satisfied & $\begin{array}{c}\text { Very } \\
\text { satisfied }\end{array}$ & \multirow{2}{*}{$\begin{array}{c}\text { Satisfaction } \\
\text { score }\end{array}$} \\
\hline & & & 0.1 & 0.3 & 0.5 & 0.7 & 1 & \\
\hline Service speed & 29 & 0.246 & 3 & 11 & 40 & 50 & 14 & 0.615 \\
\hline Service price & 25 & 0.220 & 4 & 10 & 45 & 47 & 12 & 0.600 \\
\hline $\begin{array}{l}\text { Service } \\
\text { attitude }\end{array}$ & 12 & 0.102 & 5 & 15 & 45 & 47 & 6 & 0.563 \\
\hline $\begin{array}{c}\text { Service } \\
\text { accuracy }\end{array}$ & 21 & 0.179 & 4 & 8 & 30 & 60 & 16 & 0.642 \\
\hline Integrity & 16 & 0.141 & 8 & 17 & 40 & 45 & 8 & 0.554 \\
\hline $\begin{array}{l}\text { Information } \\
\text { timeliness }\end{array}$ & 8 & 0.071 & 3 & 2 & 42 & 61 & 10 & 0.632 \\
\hline $\begin{array}{c}\text { Error } \\
\text { processing } \\
\text { quality }\end{array}$ & 3 & 0.030 & 6 & 12 & 43 & 49 & 8 & 0.576 \\
\hline Perceived risk & 1 & 0.011 & 5 & 11 & 38 & 51 & 13 & 0.606 \\
\hline Total & 118 & 1 & & Overall $\mathrm{cu}$ & er satisfac & & & 0.603 \\
\hline
\end{tabular}

Suppose $Y_{i}(i=1,2, \cdots, n=8)$ respectively represents logistics service speed, service price, service attitude, service accuracy, integrity, information quality, error processing quality and customer perceived risk. S represents satisfaction. $W_{i}$ represents the weight of the satisfaction index $Y_{i}$ to Satisfaction $\mathrm{S}$; thus, $W_{1}+W_{2}+\cdots+W_{n}=1 . q_{i j}$ represents the customer's judgment on the index $Y_{i}$ at $\mathrm{j}$ level. The judgment can be five types, i.e. very satisfied, satisfied, general, not very satisfied, not satisfied at all, that is $q_{i}=(1,0.7,0.5,0.3,0.1), j=1,2, \cdots, m=5 . k_{i j}$ represents the number of customers who assess the satisfaction level of index $Y_{i}$ at $q_{i j}$ (table 7).

After calculating the weighted average of each evaluation index (as shown below), we obtain customers' satisfaction for third-party logistics service quality in the network shopping, which equals to $60.3 \%$.

$$
S=\frac{\sum_{i=1}^{n} \sum_{j=1}^{m} q_{i j} k_{i j} W_{i}}{\sum_{i=1}^{n} \sum_{j=1}^{m} q_{i j} k_{i j} W_{i} \mid k_{i j}=1} \times 100 \%=60.3 \%
$$

Comparing the calculated results with the above scale rating table, we can see the overall customer satisfaction on the third-party logistics service quality for the current online shopping environment is just ranked in the "general" level.

\subsection{A Quadrifid Graph for Satisfaction and Importance}

Based on the importance and satisfaction score, this paper draws a quadrifid graph for the quality of logistics service under the network shopping, and enterprise can develop different strategies according to the index of different quadrant. According to the median $(0.603,0.121)$ of satisfaction and importance, horizontal axis and vertical axis are divided into four quadrants, i.e. advantage area (importance and satisfaction degree is very high), repair area (important degree is high, but low customer satisfaction), opportunity area (less important, customer satisfaction is low) and maintenance area (customer satisfaction is higher, low degree of important). The result is shown in figure 1.

Figure 1 shows that the logistics price is in the place between repair area and advantage areas, i.e. it related to a high importance and a lower satisfaction. Moreover, the integrity obtains the lowest satisfaction judgment in the repair area. To improve the logistics service price, the following points need to be considered. First, the charge standard had better be publicly showed and explained on the internet; let the customer know himself how much to pay. Second, due to special reasons such as bad weather, when the price needs to be changed, the information should be promptly updated. 


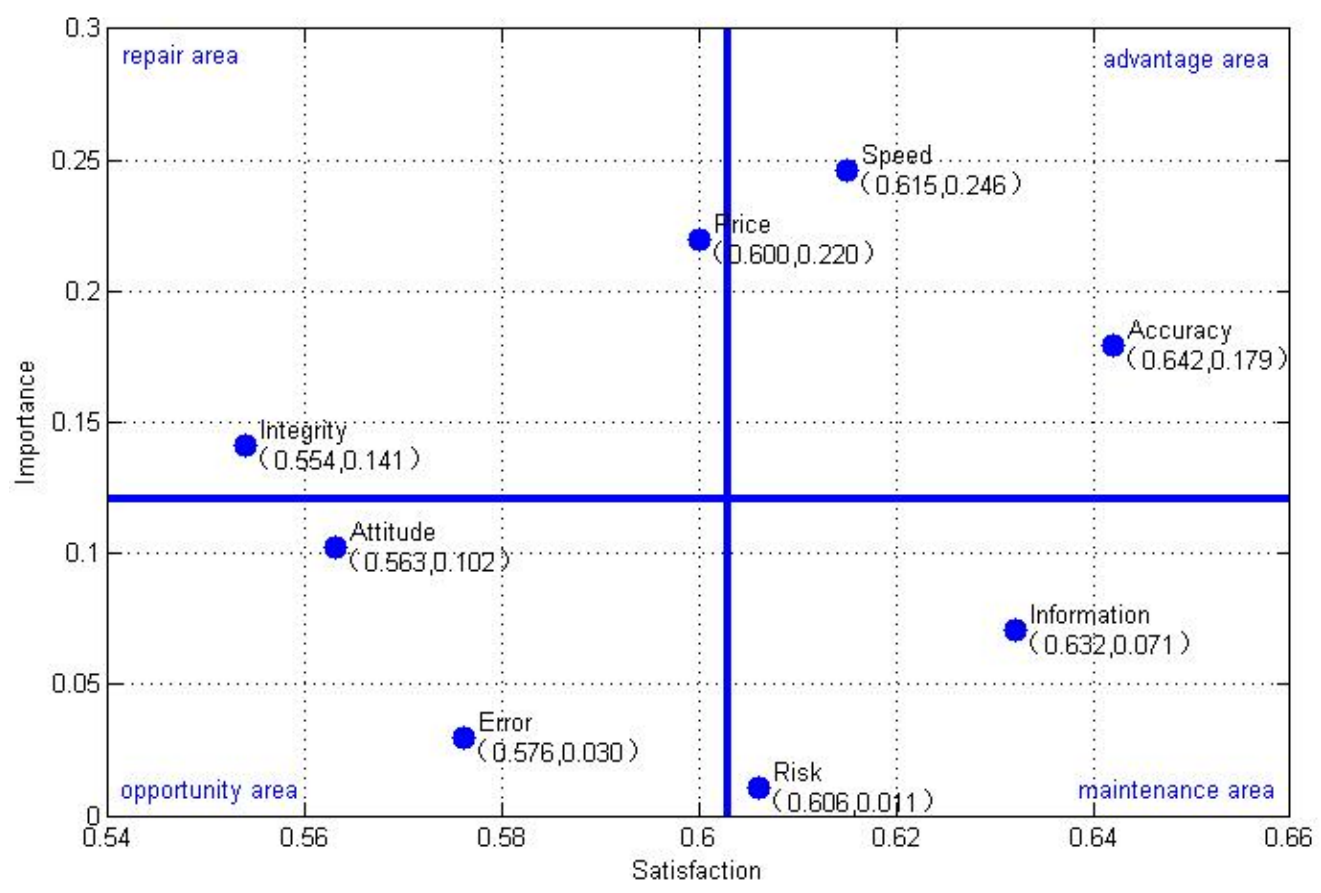

Figure 1. Importance - satisfaction graph for the third party logistics

We should make a timely response if the satisfaction of customers for integrity is extremely low. In order to improve the integrity, first, we should establish perfect responsibility system. Logistics personnel need to bear the corresponding responsibility if he damages the goods. Second, we should actively contact outlets especially when goods are easily damaged. The special packaging is needed in case; the logistics company should classify goods according to the features of the goods.

Logistics service speed is in the advantage area with the highest significance and the relatively high satisfaction. Logistics service accuracy is also located in the advantage area with the relatively low satisfaction and the highest significance. $61.5 \%$ of customers regard the logistics speed as the most important factor of customer satisfaction. To improve the speed of logistics service, we suggest optimizing transport routes and delivering goods as soon as possible. Moreover, attention should be paid on the delivery of the last kilometer. Precisely, the goods need to be classified according to the destination area and then the delivery repetition is avoided for the goods sent in the adjacent area. Once delivery delay occurs because of bad weather, holidays and other special reasons, the third party logistics company needs to explain to the customer in time to win the understanding of the customer. To improve the accuracy of the logistics service, the third party logistics enterprise can consider the operation with the China Post who has a large network coverage.

Error processing quality is in the opportunity area. To improve the satisfaction with the quality of error handling, firstly the complaint channels need to be expanded. Secondly, a complaint response mechanism should be built to ensure that logistics service personnel can make effective responses to customer complaints in the potentially shortest time. Service attitude stays in the place between opportunity area and repair areas. If the attitude of service personnel needs to be the enterprise's reputation, service attitude needs should be further improved.

Logistics information timeliness is in the maintenance area, which means that the customers are satisfied. The third-party logistics enterprises can selectively improve according to their situation. If the enterprise fund is limited, logistics enterprises can maintain the status quo; otherwise, it is worth updating and expanding the logistics information network to enhance the overall level of logistics information. Although risk perception factor located in maintenance area, the customer satisfaction is not very high. To improve customer satisfaction on the perceived risk, it is necessary to strengthen enterprise risk management system and improve the quality of the courier staff to reduce the potential source of customer perceived risk and consumer complaints.

\section{Conclusions}

Compared with the rapid development of e-commerce, low logistics service quality has been the "short board", which restricts the development of the electronic commerce. It is necessary to analyze the influence factors of the low logistics service quality. Based on the characteristics of online shopping, including logistics service speed, service price, service attitude, service accuracy, integrity, information quality, error processing quality and customer perceived risk, this paper constructed an index system for the customer satisfaction on the logistics service. With the analysis on our questionnaire survey data, it is found that the 
customer satisfaction on the third-party logistics service quality in online shopping is $60.26 \%$, i.e. customer satisfaction only reaches the "general" level. Among various evaluation index, our data show that customers regard the perceived risk least important and believe the logistics service speed with the highest importance. Moreover, consumers are highest satisfied on the accuracy and lowest satisfied on the integrity of goods. To enhance customer satisfaction for the third party logistics services, the third-party enterprises should emphatically increase the speed of logistics service and improve integrity.

\section{Acknowledgements}

The Study on Monitoring and Early Warning and its Policy Simulation of Strategic Emerging Industry Development in Jiangxi Province (71363020). The National Natural Science Fund Project (71463023), the Youth Project of Humanities and Social Science Research Fund of Ministry of Education (14YJCZH114), "Twelfth five-year" Social and Scientific Planning Project of Jiangxi Province(2015YJ302), open projects of Jiangxi Advanced Research Center of E-commerce Engineering.

\section{REFERENCES}

[1] Bernhardt K.L., Donthu N., and Kennett P.A. A Longitudinal Analysis of Satisfaction and Profitability. Journal of Business Research.2013, 47(2):161-171

[2] Collier D.A. New Marketing Mix Stresses Service. Journal of Business Strategy, 1991, 12(2): 42-45.

[3] Esper T.L, Thomas D.J., Fernanda L T., Burton S. The Last Mile: an Examination of Effects of Online Retail Delivery Strategies on Consumers. Journal of Business Logistics, 2010, 24(2): 177- 203.
[4] Huang Fei, Wang Jia. An Empirical Study of Logistics Service Quality Evaluation of Online Shopping in China. Technology Economy and Management Research, 2014(10): 174-175.

[5] Li Tao. Customer Perceived Risk Research of the Third-party Logistics. Chengdu: Southwest University of Finance and Economic. Master's degree thesis, 2013.

[6] Lin Min-hui. Logistics Bottlenecks in the Network Shopping. Journal of Logistics and Purchasing in China, 2013(21): 74-75.

[7] Mentzer J.T., Flint D.J. and Kent J.L. Developing a Logistics Service Quality Scale. Journal of Business Logistics, 1999, 20(1): 9-32.

[8] Mentzer J.T., Flint D.J. and Hult T.M. Logistics Service Quality As a Segment-Customized Process. Journal of Marketing, 2001, 65 (2): 82-104.

[9] Oliver, Richard L. Why Consumer Loyalty?. Journal of Marketing, 1999, 63(4): 33-44.

[10] Stank T. P., Thomas J.G., Shawnee K.V., and Katrina Savitskie. Logistics Service Performance: Estimating its Influence on Market Share. Journal of Business Logistics, 2003, 4(1): 27-56.

[11] Urban G.L., Fareena S., and William J Q. Placing Trust at the Center of Your Internet Strategy. Sloan Management Review, 2005, 42(1):39- 48.

[12] Wang Jing, Li Jin-fei. Customer Satisfaction Evaluation of The Third-party Logistics Service. Industrial Engineering, 2006(2): 91- 94.

[13] Xu Hao-jie. Service Quality Evaluation of SERVQUAL and Case Study of Logistics Service Customer Satisfaction. Storage and transportation in China, 2010(5): 81-82.

[14] Ye Zuo-linag, Cai Li, et al. An Empirical Study of 3PL Service Quality and C2C Customer Satisfaction. Scientific research management, 2011(8): 119-126.

[15] Zheng Bing, Jin Yu-fang, et al. Creation and Empirical Test of Local Logistics Service Quality Evaluation Index. Management review, 2007(4): 49-55. 